\title{
Phylogeography of the widespread Caribbean spiny orb weaver Gasteracantha cancriformis
}

\author{
Lisa Chamberland ${ }^{\text {Corresp., } 1}$, Fabian C Salgado-Roa ${ }^{2}$, Alma Basco ${ }^{3}$, Amanda Crastz-Flores ${ }^{4}$, Greta J Binford ${ }^{5}$, Ingi \\ Agnarsson $^{1,6}$ \\ 1 Department of Biology, University of Vermont, Burlington, Vermont, United States \\ Biology Program, Faculty of Natural Sciences and Mathematics, Universidad del Rosario, Bogota, Colombia \\ 3 University of Puerto Rico at Rio Piedras, San Juan, Puerto Rico \\ 4 Universidad Metropolitana (now Ana G. Mendez University), San Juan, Puerto Rico \\ Department of Biology, Lewis and Clark College, Portland, Oregon, United States \\ 6 \\ Corresponding Author: Lisa Chamberland \\ Email address: Ichambe1@uvm.edu
}

Background. Modern molecular analyses are often inconsistent with pre-cladistic taxonomic hypotheses, frequently indicating higher richness than morphological taxonomy estimates. Among Caribbean spiders, widespread species are relatively few compared to the prevalence of single island endemics. The taxonomic hypothesis Gasteracantha cancriformis circumscribes a species with profuse variation in size, color, and body form. Distributed throughout the Neotropics, G. cancriformis is the only morphological species of Gasteracantha in the New World in this globally distributed genus.

Methods. We inferred phylogenetic relationships across Neotropical populations of Gasteracantha using three target genes. Within the Caribbean, we estimated genetic diversity, population structure, and gene flow among island populations.

Results. Our findings revealed a single widespread species of Gasteracantha throughout the Caribbean, G. cancriformis, while suggesting two recently divergent mainland populations that may represent separate species, diverging linages, or geographically isolated demes. The concatenated and $\mathrm{COI}$ (Cytochrome c oxidase subunit 1) phylogeny supported a Caribbean clade nested within the New World. Genetic variability was high between island populations for our $\mathrm{COI}$ dataset; however, gene flow was also high, especially between large, adjacent islands. We found structured genetic and morphological variation within G. cancriformis island populations; however, this variation does not reflect genealogical relationships. Rather, isolation by distance and local morphological adaptation may explain the observed variation. 


\section{Phylogeography of the widespread Caribbean spiny orb weaver Gasteracantha cancriformis}

Lisa Chamberland ${ }^{1}$, Fabian C. Salgado-Roa ${ }^{2}$, Alma Basco ${ }^{3}$, Amanda Crastz-Flores ${ }^{4}$, Greta J. Binford $^{5}$, and Ingi Agnarsson ${ }^{1,6}$

${ }^{1}$ Department of Biology, University of Vermont, Burlington, VT, USA

${ }^{2}$ Biology Program, Faculty of Natural Sciences and Mathematics, Universidad del Rosario, Carrera. 24 No. 63C-69, Bogota, DC 111221, Colombia

${ }^{3}$ University of Puerto Rico at Rio Piedras, San Juan, Puerto Rico 00931

${ }^{4}$ Universidad Metropolitana (now Ana G. Mendez University), San Juan, Puerto Rico 00928

${ }^{5}$ Department of Biology, Lewis and Clark College, Portland, OR, USA

${ }^{6}$ Department of Entomology, National Museum of Natural History, Smithsonian Institution, Washington, DC, USA

Corresponding Author:

Lisa Chamberland

109 Carrigan Drive, 120A Marsh Life Science Building, Department of Biology, University of Vermont, Burlington, VT, 05405, USA

Email address: chamberlandlisa8@gmail.com 


\section{Abstract}

2 Background. Modern molecular analyses are often inconsistent with pre-cladistic taxonomic

3 hypotheses, frequently indicating higher richness than morphological taxonomy estimates.

4 Among Caribbean spiders, widespread species are relatively few compared to the prevalence of

5 single island endemics. The taxonomic hypothesis Gasteracantha cancriformis circumscribes a

6 species with profuse variation in size, color, and body form. Distributed throughout the

7 Neotropics, G. cancriformis is the only morphological species of Gasteracantha in the New

8 World in this globally distributed genus.

9 Methods. We inferred phylogenetic relationships across Neotropical populations of

10 Gasteracantha using three target genes. Within the Caribbean, we estimated genetic diversity,

11 population structure, and gene flow among island populations.

12 Results. Our findings revealed a single widespread species of Gasteracantha throughout the

13 Caribbean, G. cancriformis, while suggesting two recently divergent mainland populations that may represent separate species, diverging linages, or geographically isolated demes. The concatenated and COI (Cytochrome c oxidase subunit 1) phylogeny supported a Caribbean clade nested within the New World. Genetic variability was high between island populations for our COI dataset; however, gene flow was also high, especially between large, adjacent islands. We found structured genetic and morphological variation within G. cancriformis island populations; however, this variation does not reflect genealogical relationships. Rather, isolation by distance and local morphological adaptation may explain the observed variation.

\section{Introduction}

Tropical island archipelagos are some of the most biodiverse and species-rich ecosystems on the planet (Mittermeier et al., 2011). As spatially discrete microcosms, islands are exemplary models for studying evolutionary patterns and processes (Hedges, 2001; Ricklefs \& Bermingham, 2008; Hedges, 2001). While local habitat heterogeneity may generate diverse ecological niches providing opportunities for adaptive radiations (Gillespie \& Roderick, 2002; Gillespie, 2004), barriers between (e.g. oceans) and within (e.g. mountain ranges, rivers, valleys) islands likely operate more rapidly in initial diversification of linages newly colonizing oceanic archipelagos. The Caribbean islands are a biodiversity hotspot, rich in endemic species (Mittermeier \& Goettsch Mittermeier, 2005; Ricklefs \& Birmingham, 2008). Heterogeneous local environments and diverse and time-deep geological histories (Gillespie \& Roderick, 2014) have generated a kaleidoscope of communities resulting from historical evolutionary and current ecological selection (Antonelli \& Sanmartin, 2011; Smith et al., 2014). The Caribbean Sea is characterized by volcanic activity and mid-ocean ridges along the Great Caribbean arc (Pindell \& Barrett, 1990; Pindell et al., 2006). Darwinian (oceanic) islands, (Gillespie \& Roderick, 2002) are formed de novo often along subduction zones and geologic hotspots; these islands were never connected to the mainland and are surrounded by deep oceanic barriers. Oceanic islands can have both volcanic and sedimentary (e.g. Lesser Antilles, Bermuda) and non-volcanic (e.g limestone islands of the Bahamas) origins. Species compositions on these islands are characterized by longdistance dispersals (LDD) (de Queiroz, 2005; Cowie \& Holland, 2006; Gillespie et al., 2012). Conversely, continental islands once shared ancient subaerial connections to the mainland during periods of low sea levels and have subsequently flooded. The Greater Antilles are hypothesized to have shared an ancient (33-35 My) subaerial connection to South America via the Greater Antilles Aves Ridge (GAARlandia) (Iturralde-Vinent \& MacPhee, 1999; Iturralde-Vinent, 2006), which would have opened passageways for flora and fauna to readily disperse until subsequently 
46 diversifying following vicariance events. There is an historical and ongoing debate in the field of

47 biogeography regarding the relative importance of LDD versus vicariance in diversification and

48 distributions of species (e.g. Ali, 2012; Agnarsson, Ali, \& Barrington, 2019). Contemporary

49 biogeographic studies have revealed that both LDD and vicariance are important for the

50 distributions of many lineages within the Caribbean (Hedges, 1996; Cowie \& Holland, 2006;

51 Holland \& Cowie, 2007; Chamberland et al., 2018; Candek et al., 2019; Tong, Binford, \&

52 Agnarsson, 2019; Crews \& Esposito, 2020).

53

54

55

56

57

58

59

60

61

62

63

64

65

66

67

68

69

Islands have been used extensively as tools for studying dispersal patterns because oceans act as tough filters against taxa with low vagility (Cowie \& Holland, 2006). A lineage's biogeography is often dependent on a combination factors including dispersal ability, breadth of habitat suitability, and competition. Higher dispersal propensity typically results in more gene flow and thus lower genetic structure between populations. Alternatively, taxa with poor dispersal capacity often display higher genetic structure with evolutionary histories that more closely mirror geologic histories. Many arachnids are excellent models for studying biogeographic and evolutionary questions. Spiders, in particular, have evolved diverse web architecture and hunting strategies that presumably allowed them to occupy an impressive range of ecological niches (Blackledge et al. 2009). They also have a wide range of dispersal abilities - many spiderlings, for example, can disperse over incredible distances by releasing strands of silk into the air that are then carried off by wind (Bell et al., 2005), a process known as 'ballooning'. The majority of Caribbean arachnids that have undergone biogeographic analyses are short-range endemics (Cosgrove et al., 2016; Esposito et al., 2015, McHugh et al., 2014; Dziki et al., 2015; Agnarsson et al., 2018; Chamberland et al., 2018; Tong, Binford, \& Agnarsson, 2019, Čandek et al., 2019) with a few widespread species. Wider ranging species are restricted to lineages with high vagility (Esposito et al., 2015; Crews \& Gillespie, 2010; Cosgrove et al., 2016; Agnarsson et al., 2016) and a handful of species associated with humans (Crews \& Gillespie, 2010). A relatively small portion of the Caribbean biota represents 'widespread species' shared among islands and with neighboring continental landmasses (Losos, 1996; Ricklefs \& Birmingham 2008; Claramunt et al., 2012; Dziki et al., 2015; Agnarsson et al., 2016; Deler-Hernandez, 2017; Čandek et al., 2020).

Gasteracantha, the spiny-backed orb weaver, is a widespread spider genus (70 species described globally). These spiders build large orb webs in open areas (Levi, 1978) and are remarkably cosmopolitan often affixing their webs to buildings (Edmunds \& Edmunds, 1986). Their webs are characterized by conspicuous silk structures that alert large animals of their presence thus preventing accidentally collisions (Jaffé et al., 2006; Eberhard, 2007). Gasteracantha have colorful abdomens with hard, sclerotized spines. Body coloration among spiders can serve as visual lures for mating (Li et al., 2008, Lim, Land, \& Li, 2007) and prey capture (Hauber 2002; Tso et al., 2006, 2007; Fan, Yang, \& Tso, 2009; Blamires et al., 2011, Rao et al., 2015; White \& Kemp, 2016), as well as camouflage (Foelix, 1982; Blackledge, 1998; Oxford \& Gillespie, 1998), crypsis or predator avoidance (Foelix, 1982). Brightly colored abdomens are common among orb-weavers and have been widely studied. Still, the ecological underpinnings of interand intraspecific morphological diversity are quite varied (Oxford \& Gillespie, 1998) and remain largely unsolved within this genus (Ximenes \& Gawryszewski, 2018). The spines, which come in pairs of two or three, have been postulated to play a role in predatory defense in the similarly 
91 spiny genus Micrathena (Peckham, 1889; Edmunds \& Edmunds, 1986; Cloudsley-Thompson,

92

93

94

95

96

97

98

99

100

101

102

103

104

105

106

107

108

109

110

111

112

113

114

115

116

117

118

119

120

121

122

123

124

125

126

127

128

129

130

131

132

133

134

135

1995; Gonzaga, 2007); however, this hypothesis has never been empirically tested.

Profuse morphological variation and broad distributions within Gasteracantha have led taxonomists to debate the number of species, particularly within the Caribbean where molecular data has been absent. Since Linneus (1758) initially described G. cancriformis, eight species have been named in the New World (World Spider Catalog, 2020; Taczanowski, 1879, MelloLeitão, 1917, Thorell, 1859, Butler, 1873, C. L. Koch, 1844, Strand, 1915, Guérin, 1825, Strand, 1915, Linnaeus, 1767). Linnaeus (1767) and Levi (1971) both described a possible second fourspined species of Gasteracantha in the Americas- G. tetracantha. Levi (1996b and 2002) synonymized these into a single species, G. cancriformis, currently the only recognized species of Gasteracantha in the New World (World Spider Catalog, 2020).

Here we tested the taxonomic hypothesis and phylogeography of G. cancriformis. In particular, our goals were to: (1) use molecular data to reconstruct a phylogeny in the Neotropics; (2) examine the genetic diversity, population structure, and geographic distribution within the Caribbean; (3) assess correspondences between genetics, morphology, and geology. To accomplish these goals, we present a novel molecular phylogeny based on the most extensive sampling and first molecular dataset within the Caribbean.

\section{Materials \& Methods}

\section{Sampling}

Gasteracantha were collected (2011-2016) from Cuba, Hispaniola, Jamaica, Mona, Puerto Rico, the Lesser Antilles, Turks and Caicos (TCI), Mexico, Costa Rica, and the South Eastern United States (SEUS) using standard aerial searching and vegetation beating methods (Coddington et al., 1991). The specimens were fixed in $95 \%$ ethanol in the field and stored in $-20^{\circ} \mathrm{C}$ freezers in the lab. We obtained sequence data from GenBank for our outgroups and for additional South American Gasteracantha (data from Salgado-Roa et al., (2018)). Our outgroup species including near relatives selected based on recent phylogenetic analyses of Araneidae and Theridiidae spider families (Bond et al., 2014; Dimitrov et al., 2016; Garrison et al., 2016). Taxon sample information and GPS localities are included in Table S1. All specimens were collected under appropriate collection permits and approved guidelines. USDI National Park Service, EVER-2013-SCI-0028; Costa Rica, SINAC, pasaporte científico no. 05933, resolución no. 019-2013-SINAC; Cuba, Departamento de Recursos Naturales, PE 2012/05, 2012003 and 2012001; Dominican Republic, Ministerio de Medio Ambiente y Recur- sos Naturales, no 0577; Mexico, SEMARNAT scientific collector per- mit FAUT-0175 issued to Dr. Oscar Federico Francke Ballve, Oficio no. SGPA/DGVS/10102/13; Colombia, Authoridad Nacional de Licencias Ambientales, 18.497.666 issued to Alexander Gómez Mejía; Saba, The Executive Council of the Public Entity Saba, no 112/2013; Mar- tinique, Ministère de L'Écologie, du Développement Durable, et de L'Énergie; Nevis, Nevis Historical \& Conservation Society, no F001; Barbados, Ministry of Environment and Drainage, no 8434/56/1 Vol. II.

\section{DNA extraction, amplification, sequencing and alignment}

We extracted DNA from 148 individuals with the QIAGEN DNeasy extraction kit. We amplified two mitochondrial loci, (COI: Cytochrome c oxidase subunit I), (16S: 16SrRNA), and one nuclear loci, (ITS2: internal transcribed spacer 2), that have demonstrated successful

Peer) reviewing PDF | (2020:01:45424:1:2:NEW 19 Mar 2020) 
136 amplification and informative variation in spiders at low taxonomic levels (Agnarsson,

137 Maddison, \& Avilés, 2007; Agnarsson, 2010; Kuntner \& Agnarsson, 2011; McHugh et al.,

138 2014). PCR conditions of the three markers are described in Table S2. DNA sequences were

139 assembled using Phred and Phrap (Green, 1999; Green \& Ewing, 2002) via the Chromaseq

140 module 1.2 in Mesquite 3.4 (Maddison \& Maddison, 2015) with default parameters. Outgroup

141 sequence data were taken from Genbank (Table S1). All gene fragments were aligned in MAFFT

1427 (http://mafft.cbrc.jp/alignment/server/) under default settings. The final alignments were then

143 aligned by eye, edited and maintained in Mesquite.

144

\section{Phylogenetics and divergence time estimations}

We selected the appropriate substitution model and partitioning schemes using PartitionFinder v1.1.1 (Lanfear et al., 2012) using the 'greedy' algorithm and 'mrbayes' model according to the AIC criterion (Posada \& Buckley, 2004). We used Bayesian inference (BI) to test the phylogenetic relationships and estimate divergence times within Neotropical Gasteracantha. We generated individual gene trees for the three loci and for a concatenated dataset remotely on the CIPRES (Miller, Pfeiffer, \& Schwartz, 2010) portal using MrBayes 3.2.2 (Huelsenbeck et al., 2001; Ronquist \& Huelsenbeck, 2003). We used a concatenated phylogeny because it has been shown to perform as well as species tree methods (Tonini et al., 2015). Four BI, Markov chain Monte Carlo (MCMC) were run with two sets of four chains for 100 million generations, sampling the Markov chain every 10000 generations. All tree files were examined in Tracer v1.6 (Rambaut et al., 2014) to verify proper mixing of chains and that MCMC had reached stationarity (effective sample size, ESS $>200$ ), and to determine adequate burn-in. The burn-in was set for the first 5000 trees. We computed posterior probabilities (PP) from a majority rule consensus tree of the post-burn-in trees locally in MrBayes.

Node ages were estimated using BEAST 1.8.0 (Drummond \& Rambaut, 2007) under a relaxed clock model (Drummond et al., 2006; Drummond et al., 2012). We configured input files locally using BEAUti (Altekar et al., 2004) and then ran the BEAST analysis on the CIPRES online portal. We pruned sequences that had greater than $65 \%$ missing characters as well as redundant sequences with one individual per haplotype to avoid coalescence and zero-length branches. The most recent common ancestor (MRCA) of Araneoidea (Theridiidae + Araneidae) was calibrated using a normal distribution with mean of $170 \mathrm{Ma}(\mathrm{SD} \pm 35)$ and the age of the root as 233 (Garrison et al., 2016). The MRCA of Araneidae was set to $70 \mathrm{My}$ (SD \pm 28 ). The COI mitochondrial substitution rate parameter (ucld.mean) was set as a normal prior with mean $=$ 0.0112 and $\mathrm{SD}=0.001$; these substitution rates have been estimated to be similar across spider lineages (Bidegaray-Batista \& Arnedo, 2011; Kuntner et al., 2013; McHugh et al., 2014). The analysis was run for 60 million generations with a calibrated birth-death tree prior as it can simulate extinction rates over time and is more appropriate if more than one individual represents terminal taxa (Drummond et al., 2012). For individual gene trees and our concatenated dataset, we assessed convergence of the runs and tested for stationarity (ESS $>200)$ in Tracer. A maximum clade credibility tree was assembled in TreeAnnotator using a burn-in of 5 million generations for all three loci and for the concatenated dataset.

\section{Genetic diversity, population structure and haplotype reconstruction}

We assessed population structure and estimated genetic differentiation between Caribbean island populations of G. cancriformis. Since our main focus was within the Caribbean, we did not 
182 include the mainland species/populations for the following analyses. Using each island as

183 operational geographic unit, we ran an analysis of molecular variance (AMOVA) in Arlequin v.

1843.5 (Excoffier \& Lischer, 2010) to infer hierarchical structure across island populations. We

185 performed two AMOVAs, the first within only island populations of G. cancriformis and the

186 second with all of G. cancriformis including the mainland population. Haplotype diversity (Hd)

187 (Nei 1987), pairwise estimates of nucleotide diversity $(\pi)$ (Nei \& Tajima, 1981), and average

188 nucleotide differences $(\mathrm{K})$ were calculated in DnaSP quantify genetic heterogeneity within each

189 island. Using DnaSP, we also estimated relative $\left(F_{\mathrm{ST}}\right)$ and absolute $\left(d_{\mathrm{XY}}\right)$ differentiation between

190 island populations. We calculated Rousset's (1997) distance measure $\left.\left.\left(F_{\mathrm{ST}}\right) /\left(1-F_{\mathrm{ST}}\right)\right)\right)(100,000$

191 permutations) in Arlequin to test partitioning of genetic variation by islands in G. cancriformis.

192 Number of migrants $(\mathrm{Nm})$ was calculated in Arlequin to estimate gene flow between

193 populations. Haplotype networks were assessed using median-joining methods in PopART 1.7

194 (http://popart.otago.ac.nz) (Bandelt, Forster, \& Röhl, 1999; Leigh \& Bryant, 2015). We

195 implemented Bayesian Analysis of Population Structure (BAPS) (Cheng et al., 2013), a

196 hierarchical genetic clustering algorithm, to assess the nested population structure within $G$.

197 cancriformis using the R-package RhierBAPS (Tonkin-Hill et al., 2018). We performed two

198 separate runs testing 1-20 populations for both our mtDNA and nuclear datasets.

199

200

201

202

203

204

205

206

207

208

209

210

211

212

213

214

215

216

217

218

219

220

221

222

223

224

225

226

227

\section{Species boundaries}

DNA barcoding and genetic distance were used to test for species boundaries within Neotropical Gasteracantha. Uncorrected $\mathrm{p}$ values among and between potential species groups were calculated in Mega 7 (Kumar, Stecher, \& Tamura, 2016). We tested species boundaries using Automatic Barcode Gap Discovery (ABGD) method (Puillandre et al., 2012) rather than generalized mixed Yule-coalescent (GMYC) or Poisson tree processes (PTP) because the latter are not specifically designed to find recently diverged species and are often sensitive to high gene flow (Luo et al., 2018). The ABGD method was used through the online portal (http://www.abi.snv.jussieu.fr/public/abgd/) to identify shifts from low intraspecific distances to higher interspecific in the $C O I$ sequences. We set $\mathrm{P}$ (prior intraspecific divergence) from 0.01 to 0.1 ; steps set to $10 ; \mathrm{X}$ (minimum relative gap width) set to 1.5 ; $\mathrm{Nb}$ bins (for distance distribution) set to 20 ; we selected the Kimura (K80) model and set TS/TV to 2.0.

\section{Geographic, genetic, and morphological distances}

We tested the relationships between geographic, genetic and morphological (spine number and abdomen color) distances. We ran a Mantel test for 10,000 permutations using the R-package ecodist (Goslee \& Urban, 2007) to assess significance between genetic relatedness and geographic distance. To assess geographic and genetic patterns of polymorphisms, adult female specimens were photographed using Visionary Digital BK lab system. We used 80 adult females from the Caribbean islands for our morphological analyses. We coded a total of six color morphs - three that have been previously described within G. cancriformis by Gawryszewski (2007) (white, yellow, black and white), an all-black morph previously reported by Salgado-Roa et al., (2018), and two morphs that had not been previously reported (white and red stripes, black and yellow stripes) (Figure 1). We ran a chi-squared Monte Carlo analysis to test the association between the coloration and spine number of individuals and their genetic variation and geographic locality. Under the null hypothesis we would expect morphology (abdominal color and spine number) to be independent of island. We ran Multiple Correspondence Analysis (MCA) using the R-package FactoMineR (Husson et al., 2019) to analyze the statistical variance 
228

229

230

231

232

233

234

235

236

237

238

239

240

241

242

243

244

245

246

247

248

249

250

251

252

253

254

255

256

257

258

259

260

261

262

263

264

265

266

267

268

269

270

271

272

among our three categorical variables (island, $C O I$ haplotype, and spine number and abdominal color.

Results

Phylogenetics and divergence time estimations

The final alignment lengths for our DNA matrices were: $529-$ COI, $546-16 S$, and $506-I T S 2$, for a concatenated matrix of 1581 base pairs. The models used in the MrBayes and BEAST analyses for each of the loci were $\mathrm{HKY}+\mathrm{I}+\mathrm{G}$ for $\mathrm{COI}$, GTR $+\mathrm{G}$ for $16 \mathrm{~S}$, and $\mathrm{GTR}+\mathrm{I}+\mathrm{G}$ for ITS2. Phylogenetic inferences for both the single-gene (COI) and pruned (42 terminals) BEAST concatenated datasets indicated three clades $(\mathrm{PP}>0.75)$ within the New World-two mainland clades and a predominantly island clade that included some individuals from SEUS (Figure 2, Figure S1). The full, 209 specimen concatenated phylogeny was inconsistent with our pruned concatenated phylogeny; the two divergent populations, Caribbean and South America (west of the Andes), were nested a single New World clade. (Figure S2). We inferred phylogenetic relationships with reference to the pruned, dated topology, because of the implicit biases in in our full dataset including sampling biases, large amounts of missing data for 16S and ITS2 (particularly in Central America), and redundant sequences.

\section{Genetic diversity, population structure and haplotype reconstruction}

There is high genetic diversity, but low genetic divergence among island populations of $G$. cancriformis. The BAPS inference revealed three genetic clusters within G. cancriformis: a western cluster containing SEUS, Cuba, Jamaica, TCI, a central cluster containing Hispaniola, Mona and Puerto Rico, and an eastern cluster containing Hispaniola, Puerto Rico, and the Lesser Antilles (Table S1). Genetic variability was better explained by differences among islands (49.21\%), rather than due to changes among populations within islands $(16.75 \%$; Table 1$)$. Pairwise genetic distances and gene flow ranged from -0.00297 and 0.78772 and 0.13475 and infinity between Jamaica and TCI and between Cuba and Mona respectively (Table S3; Figure 3). Pairwise $F_{\mathrm{ST}}$ values were higher between island populations than within populations (Figure $4 \mathrm{c}$, Table S3). Lowest pairwise genetic distances were between Jamaica and TCI $\left(F_{\mathrm{ST}}\right)=-$ $0.00297)$ with gene flow reaching infinity. The highest pairwise genetic distances were between Mona and Cuba $\left.\left(F_{\mathrm{ST}}\right)=0.78772\right)$ and lowest migration rates $(\mathrm{Nm}=0.13475)($ Table S3). The nucleotide differences $\left(\mathrm{K}_{\mathrm{XY}}\right)$ and average number of nucleotide substitutions per site $\left(d_{\mathrm{XY}}\right)$ between island populations ranged from 2.1 and 0.00397 (Jamaica and TCI) to 7.6875 and 0.01453 (Jamaica and Mona) respectively (Table S4). Within the COI dataset, we found 42 unique haplotypes and high haplotype and nuclear diversity $(\mathrm{Hd}=0.9473, \mathrm{~N}=0.00973$ respectively) (Table 2). The average nucleotide differences (K) was 5.14855 among island populations. The $16 S$ dataset had fewer haplotypes $(\mathrm{h}=8)$ and less haplotype diversity $(\mathrm{Hd}=0.406, \mathrm{Nm}=0.00198)$. Haplotype and nucleotide diversity were relatively lower for islands with smaller areas, (eg. Mona and TCI) (Figure 4c, Table 2).

ABGD analyses of $C O I$ split Gasteracantha into three geographic, putative independently evolving groups, Caribbean islands, west of the Andes, and east of the Andes (Figure 2). Uncorrected COI distance p scores between the Caribbean clade and the clades east and west of the Andes were $4.1 \%$ and $6.7 \%$ respectively and $5.2 \%$ between the east and west of the Andes clades. The genetic distances between these three populations are greater than the average maximum intraspecific divergence of $0.96 \%$ across another Araneidae genus, Cyclosa (Robinson 
273

274

275

276

277

278

279

280

281

282

283

284

285

286

287

288

289

290

291

292

293

294

295

296

297

298

299

300

301

302

303

304

305

306

307

308

309

310

311

312

313

314

315

316

317

et al., 2009). Uncorrected genetic distances in COI data between and among taxon groups. Uncorrected $\mathrm{p}$ values calculated among and between groups were compared to previously determined araneae distances- $2.15 \%$ mean intraspecific divergence and $6.77 \%$ mean divergence between nearest interspecific neighboring taxa groups (Blagoev et al., 2009; Kuntner \& Agnarsson, 2011). A recent study on Gasteracantha from Malaysia and closely related sister linages recorded uncorrected $\mathrm{p}$ distances from $0.63-3.75$ within species and $7.95-14.60$ among; however, these distances were based on a four-loci dataset (Tan et al., 2019).

The relationship between geology, genetics, and morphology

We found correspondences between geology, genetics, and morphology (Figure 4b). First, we found a weak, but significant correlation between geographic and genetic distances. The Mantel test of Caribbean Gasteracantha indicated a significant correlation between genetic relatedness and geographic distance (Mantel $r=0.5306853$, $\mathrm{p}$-value $=0.0001)$. Furthermore, there was a substantial amount of intermixed and shared haplotypes among islands (Figure 3). Second, we found a significant relationship between both spine number (chi-squared $=101, \mathrm{df}=9, \mathrm{p}$-value $=$ $2.2 \mathrm{e}-16$ ) and abdominal color (chi-squared $=115.09, \mathrm{df}=30, \mathrm{p}$-value $=6.705 \mathrm{e}-12$ ) and island. The Lesser Antilles, TCI and Puerto Rico clustered tightly around four spines (Figure 4b). Both yellow and white color morphs were found on every island excluding Mona, which only had the black and white morph. All of the individuals from SEUS were white with red spines, including the divergent Floridian population. The specimens from Costa Rica were yellow with black spines. Lastly, we did not find a strong correspondence between genetic variation and morphology. Many COI haplotypes shared multiple polymorphisms (Figure 3a-c). Spine number was also more closely explained by island rather than genetic relatedness. There were instances of shared haplotypes with different spines (Figure 3); however, each island has either four or sixspined individuals, and there were no islands that shared individuals with both spine numbers (Figures 1 \& S2).

\section{Discussion}

\section{Overview}

Here, we present the first molecular and morphological analyses of Gasteracantha in the Caribbean. Using a novel molecular dataset, we find partial support for Levi's taxonomic hypothesis of a single New World species in the genus Gasteracantha, G. cancriformis with recently divergent ( $<5 \mathrm{My}$ ) populations in the Caribbean and North and South America (Figure 2). Bayesian analyses of the full, 209-specimen dataset supported a Caribbean and South American clade (east of the Andes) nested within a paraphyletic lineage (west of the Andes) (Figure S2). This paraphyly was inconsistent with our BEAST dated phylogenetic analysis, which resolved these three geographic, divergent lineages as monophyletic (Figure 2). Low genetic divergences and shared haplotypes among islands are consistent with ongoing gene flow and/or recent colonization events and imply high dispersal propensity among this lineage. We also tested whether spine number, abdominal color, or geography could predict the phylogenetic placement of Gasteracantha within the Caribbean. Spine number strongly corresponds with island whereas color is less specific to islands, with many islands sharing color morphs (Figure $1)$.

Partial support for Levi's single widespread New World species hypothesis, and divergent populations

Peer) reviewing PDF | (2020:01:45424:1:2:NEW 19 Mar 2020) 
318 We found support for a single genetic group of Gasteracantha in the Caribbean and evidence for 319 additional divergences in the New World. While the COI and concatenated BI supported a

320 divergent mainland and Caribbean lineage, there was discordance among tree topologies between

321

322

323

324

325

326

327

328

329

330

331

332

333

334

335

336

337

338

339

340

341

342

343

344

345

346

347

348

349

350

351

352

353

354

355

356

357

358

359

360

361

362

363 our pruned and full dataset. Thus, we did not find strong support for new species, and we failed to reject Levi's single New World species hypothesis. Our full concatenated phylogeny indicates two divergent populations nested within a mainland population from North and South America west of the Andes (Figure S2-S3). More specifically, the nesting of the entire New World lineage within Mexico could suggest origins in Mexico and subsequent diversification in the Caribbean and North and South America, Mexico only included COI data and was not included in our pruned phylogeny. Further sampling throughout Central America, would undoubtably be important for uncovering the biogeographic history of the genus in the Neotropics. Furthermore, posterior probabilities were extremely low (Figure S3), which is likely due to missing sequence data (Table S1) and/or identical sequences. Large amounts of missing data in conjunction with incomplete lineage sorting (ILS) can generate inconsistent and conflicting phylogenies (Xi, Liu, \& Davis, 2015). There were three diagnosable clades within the dated pruned (42 terminal) concatenated and COI phylogeny, one Caribbean clade, and two mainland clades (Figure 2). Our concatenated and COI BEAST analysis indicated three recently divergent $(<5 \mathrm{Ma})$ clades- one primarily Caribbean clade (with a few individuals from SEUS) ( $\mathrm{PP}=1$; Figure 2a), one from North, Central, and South America (west of the Andes), and one clade containing individuals east of the Andes (Orinoco, Amazon and southeastern Brazil) ( $\mathrm{PP}=76$; Figure 2b). The Andes are a large mountain range that are important drivers of diversification in South American lineages (Brumfield \& Capparella, 1996; Antonelli et al., 2009; Hoorn et al., 2010), including in ferns (Testo, Sessa, Barrington, 2018), freshwater fish (Lundberg et al., 1998), and have restricted gene flow within Gasteracantha (Salgado-Roa et al., 2018). Similarly, the Caribbean Sea is likely also playing a role in the divergence of the Caribbean Gasteracantha. While we do find evidence of migration and gene flow between Caribbean and North American populations, the oceans in between are likely limiting gene flow, but not so much as to generate new species.

There was discordance among our three individual gene trees. While the $16 S$ phylogeny showed similar topology to COI supporting two mainland clades and a Caribbean and SEUS clade, ITS2 did not recover these three clades (Figure S1). Discordance among gene trees may be an artifact of the recent divergences between island and mainland populations or a product of male-biased dispersal (Pusey, 1987; Knight et al., 1999; Aars \& Ims, 2000; Doums, Cabrera, \& Peeters, 2008), which would lead to different evolutionary histories between males and females. However, low information content of ITS2 - lack of evidence - in this study is a more likely explanation for this discordance. Sexual size dimorphism can be extreme among spiders (Kuntner \& Elgar, 2014). Females within G. cancriformis have more prominent spines and are larger (5-9 mm long, 10-13 mm wide) than the tiny (2-3 mm long) males (Muma, 1971; World Spider Catalogue, 2020). Furthermore, females remain sedentary in the web, while males will disperse and search for potential mates. More likely, however, these discordant gene trees are a consequence of differing substitution rates (Maddison, 1997; Degnan \& Rosenberg, 2009). While we find $C O I$ structure, the discordant gene trees and evidence of gene flow suggests this is more consistent with recent colonization or founder effects rather than speciation.

Species delimitation analyses revealed genetically divergent populations, uncorrected $C O I$ distance $\mathrm{p}$ scores ranged from $4.1 \%$ and $6.7 \%$ between island and mainland populations; 
364 however, this was for a single gene and discordance among our phylogenetic analyses do not

365

366

367

368

369

370

371

372

373

374

375

376

377

378

379

380

381

382

383

384

385

386

387

388

389

390

391

392

393

394

395

396

397

398

399

400

401

402

403

404

405

406

407

408

409

provide strong enough evidence for new species. Population level Next Generation Sequencing will clarify relationships and would help to recover a more robust species tree. Furthermore, future intra-specific studies on this lineage may consider more closely related outgroups based on recent Araneidae phylogenies (Scharff et al. 2019; Kallal et al. 2018). Still, given that we sampled only a portion of the distribution of G. cancriformis (N. America and the Caribbean) additional species may be expected.

\section{Genetic diversity, population structure, and geographic distribution}

Gasteracantha characterize a good dispersing lineage of spiders that colonized the Caribbean over water and have continued exchange among islands. Gene flow is high among island populations of Gasteracantha $\left(\mathrm{G}_{\mathrm{ST}}=0.22 ; \mathrm{Nm}=0.88\right)$; however, it does not entirely obfuscate a geographic signal. The largest proportion of genetic variability (49.21\%) is explained between islands for $C O I$. While $16 S$ did have genetic clustering between the two mainland populations and the islands, it did not did not have significant genetic variability $(-0.39 \%)$ between the island populations (Table 2; Figure S4) This may be due to ILS or limited molecular Caribbean data for $16 S$ and ITS2, with 29 and 26 individuals respectively. Moderate genetic structure and evidence of gene flow among island populations implies good dispersal propensity among this lineage of spiders. Similar patterns of widespread distribution are found in good dispersers (Van der Pijl, 1982) including flying animals (Cook et al., 2012), freshwater shrimp (Cook et al., 2012), saltwater resistant seeds (Stephens, 1966), and ballooning arachnids (Kuntner \& Agnarsson, 2011; Agnarsson et al., 2016). Furthermore, since Gasteracantha colonized the Caribbean much later than GAARlandia (33-35 My) would have existed, we reject the land bridge hypothesis for this lineage. The intermediate dispersal model (Agnarsson et al., 2014) predicts lineages with the intermediate dispersal abilities will have the greatest species richness. Taxa are able to disperse to islands but remain isolated enough for speciation to occur. Excellent dispersers will exhibit high gene flow among populations and consequently, their phylogeny will not be reflected in the geologic history. Gene flow within the Caribbean populations of Gasteracantha has likely prevented speciation on these islands.

\section{The relationship between geology, genetics, and morphology}

Individuals that were further apart geographically had greater genetic distances between them. Results from our Mantel test detected a significant correlation between geographic and $\mathrm{COI}$ genetic distances (Mantel $\mathrm{r}=0.5306853, \mathrm{P}=0.0001$ ). Notably, one major pitfall associated Mantel tests is that they are often subject to spatial autocorrelation and erroneously low p-values (Guillot \& Roussett, 2013). Still, this relationship between geography and genetics was also reflected in our BAPS cluster analysis (Table S1). Individuals that were geographically close also cluster within the $C O I$ phylogeny, indicating a correlation between geography and genetics, albeit relatively weak.

We found evidence that spine number was an important predictor of island locality and was highly specific to island. For instance, six-spined and four-spined Gasteracantha did not occur on the same island and neither are monophyletic (Figure $1 \&$ S2). Excluding Mona, six-spined varieties were only found on the mainland and on large islands (e.g. Cuba, Hispaniola), and fourspined varieties were typically found on the smaller islands (e.g. Lesser Antilles, TCI) (Figure 1). Results from chi-squared analyses support a strong correspondence of spine number with

Peer) reviewing PDF | (2020:01:45424:1:2:NEW 19 Mar 2020) 
410 geography (individual islands), but spine number only weakly corresponds with genetic

411 similarity. Even among shared haplotypes between Puerto Rico and Hispaniola the morphology

412 (number of abdominal spines) corresponded with geography - indicating strong selection

413 following island colonization (Figure 3a). Strong regional selection can drive two genetically

414 different lineages towards a single phenotype (e. g. Müllerian mimicry in Heliconius butterflies)

415 (Hines et al., 2011; Supple et al., 2013). Within Gasteracantha, we hypothesize that there are

416 strong selective pressures, namely predators, on each island driving spine number and coloration,

417 as suggested by recent ecological studies (Ximenes \& Gawryszewski, 2018). Birds (Rypstra,

418 1984; Wise, 1995; Foelix, 1996) and wasps (Wise,1993; Foelix, 1995; Camillo \& Brescovit,

419 2000; Camillo, 2002) are common predators of spiders. Given that Gasteracantha remain

420 conspicuous in the center of the web during the daytime and birds are primarily visual predators

421 it is likely spines play an important role in defense. Even with their hard, sclerotized exterior,

422 Gasteracantha are still often consumed by wasps (Camillo 2002, Gawryszewski \& Motta, 2012,

423 Agnarsson, 2020 pers. comm.). Future ecological studies could test whether there is a correlation

424 between endemic species of known bird predators on an island and the number of spines.

425

426 In contrast to patterns in spine number, dramatic color polymorphisms were widespread

427 throughout the Caribbean and were generally (excluding Mona) weakly geographically

428 structured. Moreover, we did not find a correspondence between genetics and color morphs. For

429

430

431

432

433

434

435

436

437

438

439

440 instance, identical COI haplotypes sometimes shared multiple color morphs (Figure 3c), thus implying strong ecological selection following island colonization. Morphological changes, including adaptive radiations, on islands can occur rapidly following isolation events (Millien, 2006). Selective pressures, founder and priority related effects, and local conditions, including temperature, solar radiation, predators can drive differential environmental adaptations between populations (Mathys \& Lockwood, 2011). Environmental heterogeneity, such as that exemplified in the Caribbean islands, (e.g. variation in light spectrums, island habitat diversity and environmental filtering) can also independently drive disruptive selection for discrete polymorphisms (Endler 1993, Oxford and Gillespie 1998, Oxford \& Gillespie, 2001). The two genetically divergent populations from SEUS are morphologically identical- all specimens are white with six red spines, a morph previously described in South America by Gawryszewski

441

442

443

444

445 (2007). Remarkably, one such morph from SEUS, which is nested within the Caribbean clade (Figure 2), also shares an identical COI haplotype with a yellow morph from Cuba (Figure 3b). This suggests that possible ecological plasticity rather than phylogenetics is driving and or maintaining these highly variant polymorphisms. It is possible that habitat diversity and heterogeneity is responsible for generating and maintaining the dramatic polymorphisms within island populations of G. cancriformis. Sampling in North and Central America was limited in this study and is important for more confidently addressing this question. Furthermore, since color polymorphisms are often represented in a small number of major loci (Ford, 1940; Chouteau et al., 2017; Gautier et al., 2018), uncovering the genetic underpinnings of these color polymorphism in Gasteracantha will be fundamental in testing the underlying selective pressures of these colors.

Color polymorphisms are paradoxical in nature; typically, genetic drift and natural selection remove variation from populations (Ford, 1964; Hartl \& Clark, 1997; Futuyma, 2005). From the 454 predator's perspective, there is a high cognitive demand for detecting cryptic species (Bond \& 455 Kamil, 2002); thus, predators will invest in searching for one morph (Poulton, 1890; Tinbergen 
456 1960; Bond, 2007); selection will drive towards one state (Mallet \& Joron, 1999; Lehtonen \&

457 Kokko, 2012). Apostatic selection (Paulson, 1973), a negative frequency-dependent selection in

458 which rarer morphs are selected upon less than expected until the predator switches to the

459 common form (Poulton, 1890; Tinbergen 1960; Clarke, 1962; Allen \& Clarke, 1968; Allen,

460 1988; Oxford \& Gillespie, 1998; Bond, 2007) may be driving these color patterns in the

461 Caribbean, has been postulated to explain the many different colors in tropical insects (Rand,

462 1967). T. grallator, the Hawaiian happy-face spider, are a classic example of discrete color

463 polymorphisms among spiders. Oxford and Gillespie (2001) discovered multiple drivers of these

464 polymorphisms on islands and found that many of them have evolved de novo on the islands.

465 Gene flow and genetic drift can also play a fundamental role in maintaining polymorphisms

466 (Fisher, 1930; Ford, 1975) as sub-optimal morphs can persist in populations with immigrating

467 new individuals providing opportunities for ongoing gene flow (Gray \& McKinnon, 2007). The

468 proposed hypotheses however are not mutually exclusive; in most instances, it is the interplay

469 between natural selection and genetic drift that maintains genetic diversity and polymorphisms

470 within a population (Slatkin, 1973; O'Hara, 2005; Saccheri et al., 2008; Iserbyt et al., 2010).

471 Future studies can tease apart these potential drivers of this remarkable diversity within $G$.

472 cancriformis.

473 Conclusions

474 We found that $G$. cancriformis includes a distinctive genetic group that is largely from the

475 Caribbean islands, which suggest that the sea is a geographic barrier that promotes genetic

476 differentiation between islands and mainland. However, little evidence of genetic divergence

477 between Caribbean islands, and lack of Caribbean monophyly are indicative of gene flow

478 between islands and continents, suggesting that this species' high vagility facilitates dispersal

479 across geographic barriers. Though we found the presence of unique phenotypes in some islands,

480 the loci that we used did not elucidated an association between patterns of genetic diversity and

481 phenotypic diversity. Gasteracantha cancriformis is an ideal model system for future studies to

482 explore ecological, evolutionary, and behavioral questions. The striking polymorphic phenotypes

483 within this species include characters that are closely associated with geography (spine number)

484 and characters that are not (color), leaving much to learn about ecological and behavioral factors

485 that influence the evolutionary maintenance of this color polymorphism. NGS and/or RADseq

486 data would provide higher resolution for testing population level relationships as well as patterns

487 of gene flow and migration between islands.

488

489

490

491

492

493

494

495

496

497

\section{Acknowledgements}

We thank all the members of the CarBio team. We are especially grateful to Anne McHugh, Carol Pfeiffer, and Laura Caicedo for their help collecting specimens. We would also like to thank Morgan Southgate and Federico Lopez-Osorio for their help with the data analyses. We would also like to thank David Barrington for providing feedback on an early version of the manuscript.

\section{References}

Aars J, Ims, RA. 2000. Population dynamics and genetic conse- quences of spatial density-dependent dispersal in patchy populations. The American Naturalist 155(252265) DOI: $10.1086 / 303317$. 
498

499

500

501

502

503

504

505

506

507

508

509

510

511

512

513

514

515

516

517

518

519

520

521

522

523

524

525

526

527

528

529

530

531

532

533

534

535

536

537

538

539

540

541

542
Agnarsson I, Maddison WP, Avilés L. 2007. The phylogeny of the social Anelosimus spiders (Araneae: Theridiidae) inferred from six molecular loci and morphology. Molecular phylogenetics and evolution 43(3):833-851 DOI: 10.1016/j.ympev.2006.09.011.

Agnarsson, I. 2010. The utility of ITS2 in spider phylogenetics: notes on prior work and an example from Anelosimus. The Journal of Arachnology 38(2):377-383 DOI: 10.1636/B10-01.1.

Agnarsson I, LeQuier SM, Kuntner M, Cheng RC, Coddington JA, Binford G. 2016. Phylogeography of a good Caribbean disperser: Argiope argentata (Araneae, Araneidae) and a new "cryptic" species from Cuba. ZooKeys 2016(625): 25-44. DOI: 10.3897/zookeys.625.8729.

Agnarsson I, Van Patten C, Sargeant L, Chomitz B, Dziki A, Binford G. 2018. A radiation of the ornate Caribbean 'smiley-faced spiders' - with descriptions of 15 new species (Araneae, Theridiidae, Spintharus). Zoological Journal of the Linnean Society 182:758-790 DOI: 10.1093/zoolinnean/zlx056.

Agnarsson I, Ali JR, Barrington DS. 2019. Vicariance Biogeography. Ecology. DOI: 10.1093/obo/9780199830060-0225.

Ali JR. 2012. Colonizing the Caribbean: is the GAARlandia land-bridge hypothesis gaining a foothold?. Journal of Biogeography 39(3):431-433.

Allen JA, Clarke B. 1968. Evidence for apostatic selection by wild passerines. Nature, 220:5166, 501-502.

Allen JA. 1988. Frequency-dependent selection by predators. Philosophical Transactions of the Royal Society of London B 319:485-503 DOI: 10.1098/rstb.1988.0061.

Altekar G, Dwarkadas S, Huelsenbeck JP, Ronquist F. 2004. Parallel Metropolis coupled Markov chain Monte Carlo for Bayesian phylogenetic inference. Bioinformatics 20:407415 DOI: 10.1093/bioinformatics/btg427.

Antonelli A, Quijada-Mascareñas A, Crawford AJ, Bates JM, Velazco PM, Wüster W. 2009. Molecular studies and phylogeography of Amazonian Tetrapods and their relation to geological and climatic models. In C. Hoorn \& F. P. Wesselingh(Eds.), Amazonia: Landscape and species evolution (pp. 386-404). London, UK: Wiley-Blackwell Publishing Ltd. DOI: 10.1002/9781444306408.ch24.

Antonelli A, Sanmartín I. 2011. Why are there so many plant species in the Neotropics?. Taxon 60(2):403-414.

Bandelt H, Forster P, Röhl A. 1999. Median-joining networks for inferring intraspecific phylogenies. Mol Biol Evol 16(1):37-48 DOI: 10.1093/oxfordjournals.molbev.a026036.

Bell JR, Bohan DA, Shaw EM, Weyman GS. 2005. Ballooning dispersal using silk: world fauna, phylogenies, genetics and models. Bulletin of Entomological Research 95:69-114 DOI: 10.1079/BER2004350.

Bidegaray-Batista L, Arnedo MA, 2011 Gone with the plate: the opening of the Western Mediterranean basin drove the diversification of ground-dweller spiders. Bio Med Cent. Evol. Biol. 11:317 DOI: 10.1186/1471-2148-11-317.

Blackledge TA. 1998. Stabilimentum cariation and foraging success in Argiope aurantia and Argiope trifasciata (Araneae:Araneidae). The Zoological Society of London, 246:21-27 DOI: 10.1111/j.1469-7998.1998.tb00128.x.

Blackledge T, Wenzel J. 2001. Silk mediated defense by an orb web spider against predatory mud-dauber wasps. Behaviour 138(2):155-171 DOI: 10.1163/15685390151074357.

Peer) reviewing PDF | (2020:01:45424:1:2:NEW 19 Mar 2020) 
543 Blagoev G, Hebert P, Adamowicz S, Robinson E. 2009. Prospects for using DNA barcoding to identify spiders in species-rich genera. ZooKeys, 16:27.

Blamires SJ, Lai CH, Cheng RC, Liao CP, Shen PS, Tso IM. 2011. Body spot coloration of a nocturnal sit-and-wait predator visually lures prey. Behavioral Ecology 23(1):69-74 DOI: 10.1093/beheco/arr152.

Bond AB, \& Kamil AC. 2002. Visual predators select for crypticity and polymorphism in virtual prey. Nature 415(6872):609-613 DOI: 10.1038/415609a.

Bond AB. 2007. The evolution of color polymorphism: Crypticity, searching images, and apostatic selection. Annual Review of Ecology, Evolution, and Systematics 38:489-514. DOI: 10.1146/annurev.ecolsys.38.091206.095728.

Bond JE, Garrison NL, Hamilton CA, Godwin RL, Hedin MC, Agnarsson I. 2014. Phylogenomics resolves a spider backbone phylogeny and rejects a prevailing paradigm for orb web evolution. Curr. Biol. 24:1-6 DOI: 0.1016/j.cub.2014.06.034

Brumfield RT, Capparella AP. 1996. Historical diversification of birds in northwestern South America: A molecular perspective on the role of vicariant events. Evolution 50(4):1607 DOI: $10.2307 / 2410897$.

Camillo E, \& Brescovit AD. 2000. Spider prey (Araneae) of Trypoxylon (Trypargilum) rogenhoferi (Hymenoptera: Sphecidae) in southeastern Brazil. Revista de biologia tropical 48(2-3):647-656.

Camillo E. 2002. The natural history of the mud-dauber wasp Sceliphron fistularium (Hymenoptera: Sphecidae) in southeastern Brazil. Revista de biología tropical 127-134.

Čandek K, Agnarsson I, Binford GJ, Kuntner M. 2020. Caribbean golden orbweaving spiders maintain gene flow with North America. Zoologica Scripta 49(2):210-221 DOI: 10.1111/zsc.12405.

Chamberland L, McHugh A, Kechejian S, Binford GJ, Bond JE, Coddington J, Dolman G, Hamilton CA, Harvey MS, Kuntner M, Agnarsson I. 2018. From Gondwana to GAARlandia: Evolutionary history and biogeography of ogre-faced spiders (Deinopis). Journal of Biogeography 45(11):2442-2457 DOI: 10.1111/jbi.13431.

Cheng Lu, Connor TR, Sirén J, Aanensen DM, Corander J. 2013. Hierarchical and spatially explicit clustering of DNA sequences with BAPS software. Molecular Biology and Evolution 30(5):1224-28 DOI: 10.1093/molbev/mst028.

Chouteau M, Llaurens V, Piron-Prunier F, Joron M. 2017. Polymorphism at a mimicry supergene maintained by opposing frequency-dependent selection pressures. Proceedings of the National Academy of Sciences 114(31):8325-8329 DOI: 10.1073/pnas.1702482114.

Claramunt S, Derryberry EP, Remsen J, Brumfield RT. 2012. High dispersal ability inhibits speciation in continental radiation of passerine birds. Proc B. 279:1567-1574 DOI: 10.1098/rspb.2011.1922.

Clarke B. 1962. Balanced polymorphism and the diversity of sympatric species. Taxonomy and geography.

Cloudsley-Thompson JL. 1995. A review of the anti-predator devices of spiders. Bulletin of the British Arachnological Society 10(3):81-96.

Coddington JA, Griswold CE, Silva D, Peñaranda E, Larcher SF. 1991. Designing and testing sampling protocols to estimate biodiversity in tropical ecosystems. In: Dudley EC, ed. The Unity of Evolutionary Biology: Proceedings of the Fourth International Congress of Systematic and Evolutionary Biology. Portland, OR, USA: Dioscorides Press, 44-60. 
588

589

590

591

592

593

594

595

596

597

598

599

600

601

602

603

604

605

606

607

608

609

610

611

612

613

614

615

616

617

618

619

620

621

622

623

624

625

626

627

628

629

630

631

632

633

Cosgrove JG, Agnarsson I, Harvey MS, Binford GJ. 2016. Pseudoscorpion diversity and distribution in the West Indies: Sequence data confirm single island endemism for some clades, but not others. Journal of Arachnology 44(3):257-271 DOI: 10.1636/R15-80.1.

Cowie RH, Holland BS. 2006. Dispersal is fundamental to biogeography and the evolution of biodiversity on oceanic islands. Journal of Biogeography 33(2):193-198. DOI: 10.1111/j.1365-2699.2005.01383.x.

Crews SC, Gillespie RG. 2010. Molecular systematics of Selenops spiders (Araneae: Selenopidae) from North and Central America: Implications for Caribbean biogeography. Environmental Sciences 101(2):288-322 DOI: 10.1111/j.1095-8312.2010.01494.x.

Crews SC, Esposito LA. 2020. Towards a synthesis of the Caribbean biogeography of terrestrial arthropods. BMC Evolutionary Biology, 20(1):12 DOI: 10.1186/s12862-019-1576-z

de Queiroz A. 2005. The resurrection of oceanic dispersal in historical biogeography. Trends in Ecology \& Evolution 20(2):68-73. DOI: 10.1016/j.tree.2004.11.006.

Degnan JH, Rosenberg NA. 2009. Gene tree discordance, phylogenetic inference and the multispecies coalescent. Trends in ecology \& evolution 24(6):332-340 DOI: 10.1016/j.tree.2009.01.009.

Deler-Hernández A. 2017. Taxonomy, phylogeny and phylogeografy of selected groups of aquatic beetles (Coleoptera: Hydrophilidae, Hydraenidae) of the Caribbean region.

Dimitrov D, Benavides LR, Arnedo MA, Giribet G, Griswold CE, Scharff N, Hormiga G. 2016. Rounding up the usual suspects: A standard target-gene approach for resolving the interfamilial phylogenetic relationships of ecribellate orb-weaving spiders with a new family-rank classification (Araneae, Araneoidea). Cladistics 33:221-250 DOI: 10.1111/cla.12165.

Doums C, Cabrera H, Peeters C. 2008. Population genetic struc- ture and male-biased dispersal in the queenless ant Diacamma cyaneiventre. Molecular Ecology, 11(11), 2251-2264. https://doi.org/ 10.1046/j.1365-294X.2002.01619.x.

Drummond AJ, Ho SY, Phillips MJ, Rambaut A. 2006. Relaxed phylogenetics and dating with confidence. PLoS biology 4(5) DOI: 10.1371/journal.pbio.0040088.

Drummond AJ, Rambaut A. 2007. BEAST: Bayesian evolutionary analysis by sampling trees. BMC evolutionary biology 7(1):214 DOI: 10.1186/1471-2148-7-214

Drummond AJ, Suchard MA, Xie D, Rambaut A. 2012. Bayesian phylogenetics with BEAUti and the BEAST 1.7. Mol. Biol. Evol. 29:1969-1973 DOI: 10.1093/molbev/mss075.

Dziki A, Binford GJ, Coddington JA, Agnarsson I. 2015. Spintharus flavidus in the Caribbeana 30 million year biogeographical history and radiation of a 'widespread species'. PeerJ 3(1422). DOI: 10.7717/peerj.1422.

Eberhard WG. 2007. Stabilimenta of Philoponella vicina (Araneae: Uloboridae) and Gasteracantha cancriformis (Araneae: Araneidae): Evidence against a prey attractant function. Biotropica 39(2):216-220 DOI: 10.1111/j.1744-7429.2006.00254.x.

Edmunds J, Edmunds M. 1986. The defensive mechanisms of orb weavers (Araneae: Araneidae) in Ghana, West Africa.

Endler JA. 1993. The Color of light in forest and its implications. Ecological Monographs 63(1):1-27 DOI: 10.2307/2937121.

Esposito LA, Bloom T, Caicedo-Quiroga L, Alicea-Serrano AM, Sánchez-Ruíz JA, MayCollado LJ, Binford GJ, Agnarsson I. 2015. Islands within islands: diversification of tailless whip spiders (Amblypygi, Phrynus) in Caribbean caves. Molecular Phylogenetics and Evolution, 93, 107-117 DOI: 10.1016/j.ympev.2015.07.005.

Peer) reviewing PDF | (2020:01:45424:1:2:NEW 19 Mar 2020) 
634 Excoffier L, Lischer HE. 2010. Arlequin suite ver 3.5: a new series of programs to perform

635

636

637

638

639

640

641

642

643

644

645

646

647

648

649

650

651

652

653

654

655

656

657

658

659

660

661

662

663

664

665

666

667

668

669

670

671

672

673

674

675

676

677

678

679 population genetics analyses under Linux and Windows. Molecular ecology resources 10(3):564-567 DOI: 10.1111/j.1755-0998.2010.02847.x.

Fan CM, Yang EC, Tso IM. 2009. Hunting efficiency and predation risk shapes the colorassociated foraging traits of a predator. Behavioral Ecology 20(4):808-816 DOI: 10.1093/beheco/arp064.

Fisher RA. 1930. The evolution of dominance in certain polymorphic species. The American Naturalist 64(694):385-406 DOI: 10.1086/280325.

Foelix RF. 1982. Biology of Spiders. Cambridge, MA: Harvard University Press.

Foelix RF. 1996. Biology of Spiders. New York: Oxford University Press.

Ford EB. 1940. Polymorphism and taxonomy. In: Huxley J, ed. The New Systematics. Oxford: Clarendon Press, 493-513

Ford EB. 1964 Ecological genetics. London, UK: Methuen.

Ford EB. 1975. Ecological Genetics, 4th edn. London, UK: Chapman and Hall.

Futuyma DJ. 2005. Evolution. Sunderland, MA: Sinauer Associates, Inc.

Garrison NL, Rodriguez J, Agnarsson I, Coddington JA, Griswold CE, Hamilton CA, Hedin M, Kocot KM, Ledford JM, Bond JE. 2016. Spider phylogenomics: Untangling the Spider Tree of Life. PeerJ 4(e1719) DOI: 10.7717/peerj.1719.

Gautier M, Yamaguchi J, Foucaud J, Loiseau A, Ausset A, Facon B, Gschloessl B, Lagnel J, Loire E, Parrinello H, Severac D. 2018. The genomic basis of color pattern polymorphism in the harlequin ladybird. Current Biology 28(20):3296-3302 DOI:

10.1016/j.cub.2018.08.023.

Gawryszewski FM. 2007. Policromatismo e stabilimentum em Gasteracantha cancriformis (Araneae, Araneidae): caracterização e as hipóteses da atração de presas e da proteção da teia. Brasilia, Brazil: Universidade de Brasilia.

Gawryszewski FM, Motta PC. 2012. Colouration of the orb-web spider Gasteracantha cancriformis does not increase its foraging success. Ethology Ecology \& Evolution 24(1): 23-38 DOI: $10.1080 / 03949370.2011 .582044$.

Gillespie RG, Roderick GK. 2002. Arthropods on islands: Colonization, speciation, and conservation. Annual Review of Entomology 47(1):595-632. DOI: 10.1146/annurev.ento.47.091201.145244.

Gillespie R. 2004. Community assembly through adaptive radiation in Hawaiian spiders. Science 303(5656):356-359 DOI: 10.1126/science. 1091875.

Gillespie RG, Baldwin BG, Waters JM, Fraser CI, Nikula R, Roderick GK. 2012. Long-distance dispersal: A framework for hypothesis testing. Trends in Ecology and Evolution 27(1):4755 DOI: $10.1016 /$ j.tree.2011.08.009.

Gillespie RG, Roderick GK. 2014. Evolution: geology and climate drive diversification. Nature 509(7500):297 DOI: 10.1038/509297a.

Gonzaga MO. 2007. Inimigos naturais e defesas contra predação e parasitismo em aranhas. In: Gonzaga MO, Santos AJ, Japyassú HF, eds. Ecologia e comportamento de aranhas. Rio de Janeiro: Interciência, 209-238.

Goslee SC, Urban DL. 2007. The ecodist package for dissimilarity-based analysis of ecological data. Journal of Statistical Software 22(7):1-19.

Gray, S. M., \& McKinnon, J. S. (2007). Linking color polymorphism maintenance and speciation. Trends in ecology \& evolution, 22(2), 71-79 DOI: 10.1016/j.tree.2006.10.005.

Green P. 2009. Phrap 1.090518. Retrieved from http://phrap.org.

Peer) reviewing PDF | (2020:01:45424:1:2:NEW 19 Mar 2020) 
680 Green P, Ewing B. 2002. Phred. version 0.020425c Computer program and documentation 681 available at www.phrap.org.

682

683

684

685

686

687

688

689

690

691

692

693

694

695

696

697

698

699

700

701

702

703

704

705

706

707

708

709

710

711

712

713

714

715

716

717

718

719

720

721

722

723

724

Guillot G, Rousset, F. 2013. Dismantling the Mantel tests. Methods in Ecology and Evolution 4(4):336-344 DOI: 10.1111/2041-210x.12018.

Hartl DL, Clark AG. 1997. Principles of population genetics. Sunderland, MA: Sinauer Associates, Inc.

Hauber ME. 2002. Conspicuous coloration attracts prey to a stationary predator. Ecological Entomology. 27:686-691 DOI: 10.1046/j.1365-2311.2002.00457.x.

Hedges SB. 1996. Vicariance and dispersal in Caribbean biogeography. 52:466-473

Hedges SB. 2001. Biogeography of the West Indies: an overview. In: Woods CA \& Sergile FE, eds. Biogeography of the West Indies: patterns and perspectives, 15-33.

Hines HM, Counterman BA, Papa R, De Moura PA, Cardoso MZ, Linares M, Mallet J, Reed RD, Jiggins CD, Kronforst MR, McMillan WO. 2011. Wing patterning gene redefines the mimetic history of Heliconius butterflies. Proceedings of the National Academy of Sciences 108(49):19666-19671 DOI: 10.1073/pnas.1110096108.

Holland BS, Cowie RH. 2007. A geographic mosaic of passive dispersal: population structure in the endemic Hawaiian amber snail Succinea caduca (Mighels, 1845). Molecular Ecology 16(12):2422-2435 DOI: 10.1111/j.1365-294X.2007.03246.x.

Hoorn C, Wesselingh FP, Ter Steege H, Bermudez MA, Mora A, Sevink J, Sanmartín I, Sanchez-Meseguer A, Anderson CL, Figueiredo JP, Jaramillo C. 2010. Amazonia through time: Andean uplift, climate change, landscape evolution, and biodiversity. Science 330(6006):927-931 DOI: /10.1126/science.1194585.

Huelsenbeck JP, Ronquist F, Nielsen R, Bollback JP. 2001. Bayesian inference of phylogeny and its impact on evolutionary biology. Science 294:2310-2314 10.1126/science.1065889.

Husson F, Josse J, Le S, Mazet J, Husson MF. 2019. Package 'FactoMineR'. Package FactorMineR.

Iserbyt A, Bots J, Van Gossum H, Jordaens K. 2010. Did historical events shape current geographic variation in morph frequencies of a polymorphic damselfly?. Journal of Zoology, 282(4):256-265 DOI: 10.1111/j.1469-7998.2010.00735.x.

Iturralde-Vinent MA, MacPhee RDE. 1999. Paleogeography of the Caribbean: Implications for Cenozoic biogeography. Bulletin of the American Museum of Natural History 238:1-95.

Iturralde-Vinent MA. 2006. Meso-Cenozoic Caribbean Paleogeography: Implications for the historical biogeography of the region. International Geology Review 48(9):791-827 DOI: 10.2747/0020-6814.48.9.791.

Jaffé R, Eberhard W, De Angelo C, Eusse D, Gutierrez A, Quijas S, Rodríguez A, Rodríguez M. 2006. Caution, webs in the way! Possible functions of silk stabilimenta in Gasteracantha cancriformis (Araneae, Araneidae). Journal of Arachnology 34:448-455.

Knight ME, Oppen MV, Smith HL, Rico C, Hewitt GM, Turner GF. 1999. Evidence for male-based dispersal in Lake Malawi cichlids from microsatellites. Molecular Ecology 8(9:1521-1527. DOI: 10.1046/j.1365-294x.1999.00740.x .

Kumar S, Stecher G, Tamura K. 2016. MEGA7: molecular evolutionary genetics analysis version 7.0 for bigger datasets. Molecular biology and evolution, 33(7), 1870-1874 DOI: 10.1093/molbev/msw054.

Kuntner M, Agnarsson I. 2011. Phylogeography of a successful aerial disperser: the golden orb spider Nephila on Indian Ocean islands. BMC Evolutionary Biology 11(1):119.

Peer] reviewing PDF | (2020:01:45424:1:2:NEW 19 Mar 2020) 
725

726

727

728

729

730

731

732

733

734

735

736

737

738

739

740

741

742

743

744

745

746

747

748

749

750

751

752

753

754

755

756

757

758

759

760

761

762

763

764

765

766

767

768

769

Kuntner M, Arnedo, MA, Trontelj P, Lokovsek T, Agnarsson I. 2013. A molecular phylogeny of nephilid spiders: Evolutionary history of a model lineage. Mol. Phylogenet. Evol. 69:961979 DOI: 10.1016/j.ympev.2013.06.008.

Kuntner M, Elgar MA. 2014. Evolution and maintenance of sexual size dimorphism: aligning phylogenetic and experimental evidence. Frontiers in Ecology and Evolution 2(26) DOI:10.3389/fevo.2014.00026.

Lanfear R, Calcott B, Ho SYW, Guindon S. 2012. PartitionFinder: combined selection of partitioning schemes and substitution models for phylogenetic analyses. Molecular Biology and Evolution 29(6):1695-1701. DOI: http://dx.doi.org/10.1093/molbev/mss020.

Lehtonen J, Kokko H. 2012. Positive feedback and alternative stable states in inbreeding, cooperation, sex roles and other evolutionary processes. Philosophical Transactions of the Royal Society B: Biological Sciences, 367(1586):211-221 DOI: 10.1098/rstb.2011.017.

Leigh JW, Bryant D. 2015. PopART: Full-feature software for haplotype network construction. Methods in Ecology and Evolution 6(9):1110-1116 DOI: 10.1111/2041210X.12410.

Levi HW. 1978. The American orb-weaver genera Colphepeira, Micrathena and Gasteracantha north of Mexico (Araneae, Araneidae). Bulletin of the Museum of Comparative Zoology, 148(9):417-442.

Levi HW. 1996. The American orb weavers Hypognatha, Encyosaccus, Xylethrus, Gasteracantha, and Enacrosoma (Araneae, Araneidae). Bulletin of the Museum of Comparative Zoology at Harvard College 155:89-157.

Levi HW. 2002. Keys to the genera of araneid orbweavers (Araneae, Araneidae) of the Americas. Journal of Arachnology 30:527-562 DOI: 10.1636/01618202(2002)030[0527:KTTGOA]2.0.CO;2.

Li J, Zhang Z, Liu F, Liu Q, Gan W, Chen J, Lim ML, Li D. 2008. UVB-based mate-choice cues used by females of the jumping spider Phintella vittata. Current Biology 18(9):699-703 DOI: $10.1016 /$ j.cub.2008.04.020.

Lim ML, Land MF, Li, D. 2007. Sex-specific UV and fluorescence signals in jumping spiders. Science 315(5811):481-481 DOI: 10.1126/science.1134254.

Losos JB. 1996. Ecological and evolutionary determinants of the species-area relation in Caribbean anoline lizards. Philosophical Transactions of the Royal Society B 351:847854 DOI: $10.1098 / \mathrm{rstb} .1996 .0079$.

Lundberg JG, Marshall LG, Guerrero J, Horton B, Malabarba MC, Wesselingh F. 1998. The stage for Neotropical fish diversification: a history of tropical South American rivers. Phylogeny and classification of Neotropical fishes 27:13-48.

Luo A, Ling C, Ho SY, Zhu CD. 2018. Comparison of methods for molecular species delimitation across a range of speciation scenarios. Systematic Biology 67(5):830-846 DOI: $10.1093 /$ sysbio/syy011.

Maddison WP. 1997. Gene trees in species trees. Systematic biology 46(3):523-536 DOI: 10.1093/sysbio/46.3.523.

Maddison WP, \& Maddison DR. 2015. Mesquite: a modular system for evolutionary analysis. Version 3.04. 2015.

Mallet J, Joron M. 1999. Evolution of diversity in warning color and mimicry: polymorphisms, shifting balance, and speciation. Annual review of ecology and systematics 30(1):201-233 DOI: 10.1146/annurev.ecolsys.30.1.201. 
770

771

772

773

774

775

776

777

778

779

780

781

782

783

784

785

786

787

788

789

790

791

792

793

794

795

796

797

798

799

800

801

802

803

804

805

806

807

808

809

810

811

812

813

814

815

Mathys BA, Lockwood, JL. 2011. Contemporary morphological diversification of passerine birds introduced to the Hawaiian archipelago. Proceedings of the Royal Society B: Biological Sciences 278(1716):2392-2400 DOI: 10.1098/rspb.2010.2302.

McHugh A, Yablonsky C, Binford GJ, Agnarsson I. 2014. Molecular phylogenetics of Caribbean Micrathena (Araneae: Araneidae) suggests multiple colonization events and single island endemism. Invertebrate Systematics 28(4):337-349 DOI: 10.1071/IS13051.

Miller MA, Pfeiffer W, Schwartz T. 2010. Creating the CIPRES Science Gateway for inference of large phylogenetic trees. In Proceedings of the Gateway Computing Environments Workshop (GCE), pp. 1-8. New Orleans, LA.

Millien V. 2006. Morphological evolution is accelerated among island mammals. PLoS biology 4(10) DOI: 10.1371/journal.pbio.004032.

Mittermeier RA, Goettsch Mittermeier C. 2005. Megadiversity: Earth's biologically wealthiest nation.s CEMEX publication, 501.

Mittermeier RA, Turner, WR, Larsen FW, Brooks TM, Gascon C. 2011. Global biodiversity conservation: the critical role of hotspots. In: Biodiversity hotspots. Berlin, Heidelberg: Springer, 3-22 DOI: 10.1007/978-3-642-20992-5_1.

Muma MH. 1971. Biological and behavioral notes on Gasteracantha cancriformis (Arachnida: Araneidae).

Nei M. 1987. Molecular evolutionary genetics. Columbia University Press.

Nei M, Tajima F. 1981. DNA polymorphism detectable by restriction endonucleases. Genetics 97:145-163.

O'Hara RB. 2005. Comparing the effects of genetic drift and fluctuating selection on genotype frequency changes in the scarlet tiger moth. Proc. R. Soc. B 272:211-217 DOI: 10.1098/rspb.2004.2929.

Oxford GS, Gillespie RG. 1998. Evolution and ecology of spider coloration. Jnm 43(57):619-643 DOI: 10.1146/annurev.ento.43.1.619.

Oxford, G. S., \& Gillespie, R. G. 2001. Portraits of Evolution: Studies of Coloration in Hawaiian Spiders. BioScience 51(7):521 DOI: 10.1641/00063568(2001)051[0521:POESOC]2.0.CO;2.

Paulson DR. 1973. Predator polymorphism and apostatic selection. Evolution 27(2):269-277

Peckham EG. 1889. Protective resemblances in spiders. Occasional Papers of the Natural History Society of Wisconsin 1:61-113.

Pindell JL, Barrett SF. 1990. Geological evolution of the Caribbean region: A plate tectonic perspective. In: Dengo G \& Case JE, eds. The Caribbean Region: Geological society of America. The Geology of North America, 405-432.

Pindell J, Kennan L, Stanek KP, Maresch WV, Draper G. 2006. Foundations of Gulf of Mexico and Caribbean evolution: Eight controversies resolved. Geologica Acta: An International Earth Science Journal 4(1-2).

Posada D, Buckley TR. 2004. Model selection and model averaging in phylogenetics: advantages of Akaike information criterion and Bayesian approaches over likelihood ratio tests. Systematic biology 53(5):793-808 DOI: 10.1080/10635150490522304.

Poulton EB. 1890. The colours of animals: Their meaning and use, especially considered in the case of insects. New York: Appleton.

Puillandre N, Lambert A, Brouillet S, Achaz G. 2012. ABGD, Automatic Barcode Gap Discovery for primary species delimitation. Molecular ecology 21(8):1864-1877 DOI: 10.1111/j.1365-294X.2011.05239.x.

Peer] reviewing PDF | (2020:01:45424:1:2:NEW 19 Mar 2020) 
816 Pusey AE. 1987. Sex-biased dispersal and inbreeding avoidance in birds and mammals. Trends

817

818

819

820

821

822

823

824

825

826

827

828

829

830

831

832

833

834

835

836

837

838

839

840

841

842

843

844

845

846

847

848

849

850

851

852

853

854

855

856

857

858

859

860 in Ecology \& Evolution 2:295-299 DOI: 10.1016/0169-5347(87)90081-4.

Rambaut A, Suchard MA, Xie D, Drummond AJ. 2014. Tracer v1.6, Available from http://beast.bio.ed.ac.uk/Tracer

Rand AS. 1967. Predator-prey interactions and the evolution of aspect diversity. In Atas do Simposio sobre a Biota Amazonica (Vol. 5, pp. 73-83).

Rao D, Castañeda-Barbosa E, Nuñez-Beverido N, Díaz-Fleischer F. 2015. Foraging benefits in a colour polymorphic neotropical orb web spider. Ethology 121(2):187-195 DOI: 10.1111/eth.12330.

Ricklefs R, Bermingham E. 2008. The West Indies as a laboratory of biogeography and evolution. Philosophical Transactions of the Royal Society B-Biological Sciences 363:2393-2413 DOI: 10.1098/rstb.2007.2068.

Ronquist F, Huelsenbeck, JP. 2003. MrBayes 3: Bayesian phylogenetic inference under mixed models. Bioinformatics 19:1572-1574 DOI: 10.1093/bioinformatics/btg180.

Rousset F. 1997. Genetic differentiation and estimation of gene flow from F-statistics under isolation by distance. Genetics 145(4):1219-1228.

Rypstra AL. 1984. A relative measure of predation on web-spiders in temperate and tropical forests. Oikos 129-132 DOI: 10.2307/3544758.

Saccheri IJ, Rousset F, Watts PC, Brakefield PM, Cook LM. 2008. Selection and gene flow on a diminishing cline of melanic peppered moths. Proceedings of the National Academy of Sciences 105(42):16212-16217 DOI: 10.1073/pnas.0803785105.

Salgado-Roa FC, Pardo-Diaz C, Lasso E, Arias CF, Solferini VN, Salazar C. 2018. Gene flow and Andean uplift shape the diversification of Gasteracantha cancriformis (Araneae: Araneidae) in Northern South America. Ecology and evolution 8(14):7131-7142 DOI: 10.1002/ece3.4237.

Slatkin M. 1973. Gene flow and selection in a cline. Genetics 75(4):733-756.

Smith BT, McCormack JE, Cuervo AM, Hickerson MJ, Aleixo A, Cadena CD, Perez-Eman J, Burney CW, Xie X, Harvey MG, Faircloth BC. 2014. The drivers of tropical speciation. Nature 515(7527):406 DOI: 10.1038/nature13687.

Supple MA, Hines HM, Dasmahapatra KK, Lewis JJ, Nielsen DM, Lavoie C, Ray DA, Salazar C, McMillan WO, Counterman BA. 2013. Genomic architecture of adaptive color pattern divergence and convergence in Heliconius butterflies. Genome research 23(8):1248-1257 DOI: 10.1101/gr.150615.112.

Tan J, Chan, ZY, Ong CA, Yong HS. 2019. Phylogenetic relationships of Actinacantha Simon, Gasteracantha Sundevall, Macracantha Hasselt and Thelacantha Simon spiny orbweavers (Araneae: Araneidae) in Peninsular Malaysia. Raffles Bulletin of Zoology 67 DOI: 10.26107/RBZ-2019-0003.

Testo WL, Sessa E, Barrington, DS. 2019. The rise of the Andes promoted rapid diversification in Neotropical Phlegmariurus (Lycopodiaceae). New Phytologist, 222(1):604-613 DOI: 10.1111/nph.15544.

Tinbergen L. 1960. The natural control of insects in pinewoods. Archives neerlandaises de zoologie, 13(3):265-343 DOI: 10.1163/036551660X00053.

Tong Y, Binford G, Agnarsson I. 2019. Huntsmen of the Caribbean: multiple tests of the GAARlandia hypothesis. Molecular Phylogenetics and Evolution 130: 259-268 DOI: 10.1016/j.ympev.2018.09.017. 
861 Tonini J, Moore A, Stern D, Shcheglovitova M, Ortí G. 2015. Concatenation and Species Tree 862 Methods Exhibit Statistically Indistinguishable Accuracy under a Range of Simulated $863 \quad$ Conditions. PLOS Currents Tree of Life. 1 DOI:

$864 \quad 10.1371 /$ currents.tol.34260cc27551a527b124ec5f6334b6be.

865 Tonkin-Hill G, Lees JA, Bentley SD, Frost S, Corander J. 2018. RhierBAPS: An R 866 implementation of the population clustering algorithm hierBAPS. Wellcome open 867 research, 3, 93. DOI: 10.12688/wellcomeopenres.14694.1.

868 Tso IM, Liao CP, Huang RP, Yang EC. 2006. Function of being colorful in web spiders:

869

870

871

872

873

874

875

876 attracting prey or camouflaging oneself?. Behavioral Ecology 17(4):606-613 DOI: 10.1093/beheco/ark010.

Tso IM, Huang JP, Liao CP. 2007. Nocturnal hunting of a brightly coloured sit-and-wait predator. Animal Behaviour 74(4):787-793 DOI: 10.1016/j.anbehav.2006.09.023.

Van der Pijl L. 1982. Principles of dispersal. Berlin: SpringerVerlag.

Wise, D. H. 1995. Spiders in ecological webs. Cambridge, UK: Cambridge University Press.

White, TE, Kemp DJ. 2016. Color polymorphic lures target different visual channels in prey. Evolution 70(6):1398-1408 DOI: 10.1111/evo.12948.

World Spider Catalog. 2020. World Spider Catalog. Version 21.0. Natural History Museum Bern, online at http://wsc.nmbe.ch, accessed on 1 January 2020 DOI: 10.24436/2.

Xi Z, Liu L, Davis CC. 2016. The impact of missing data on species tree estimation. Molecular Biology and Evolution 33(3):838-860 DOI: 10.1093/molbev/msv266.

Ximenes NG, Gawryszewski FM. 2018. Prey and predators perceive orb-web spider conspicuousness differently: evaluating alternative hypotheses for color polymorphism evolution. Current Zoology. 65(5):559-570 DOI: 10.1093/cz/zoy069.

884 
Figure 1

G. cancriformis phenotypes collected from Cuba, Hispaniola, Puerto Rico, Jamaica, Mona, $\mathrm{TCl}$, and the Lesser Antilles.

Four-spined morphs were exclusive to Puerto Rico, the Lesser Antilles, and TCl.
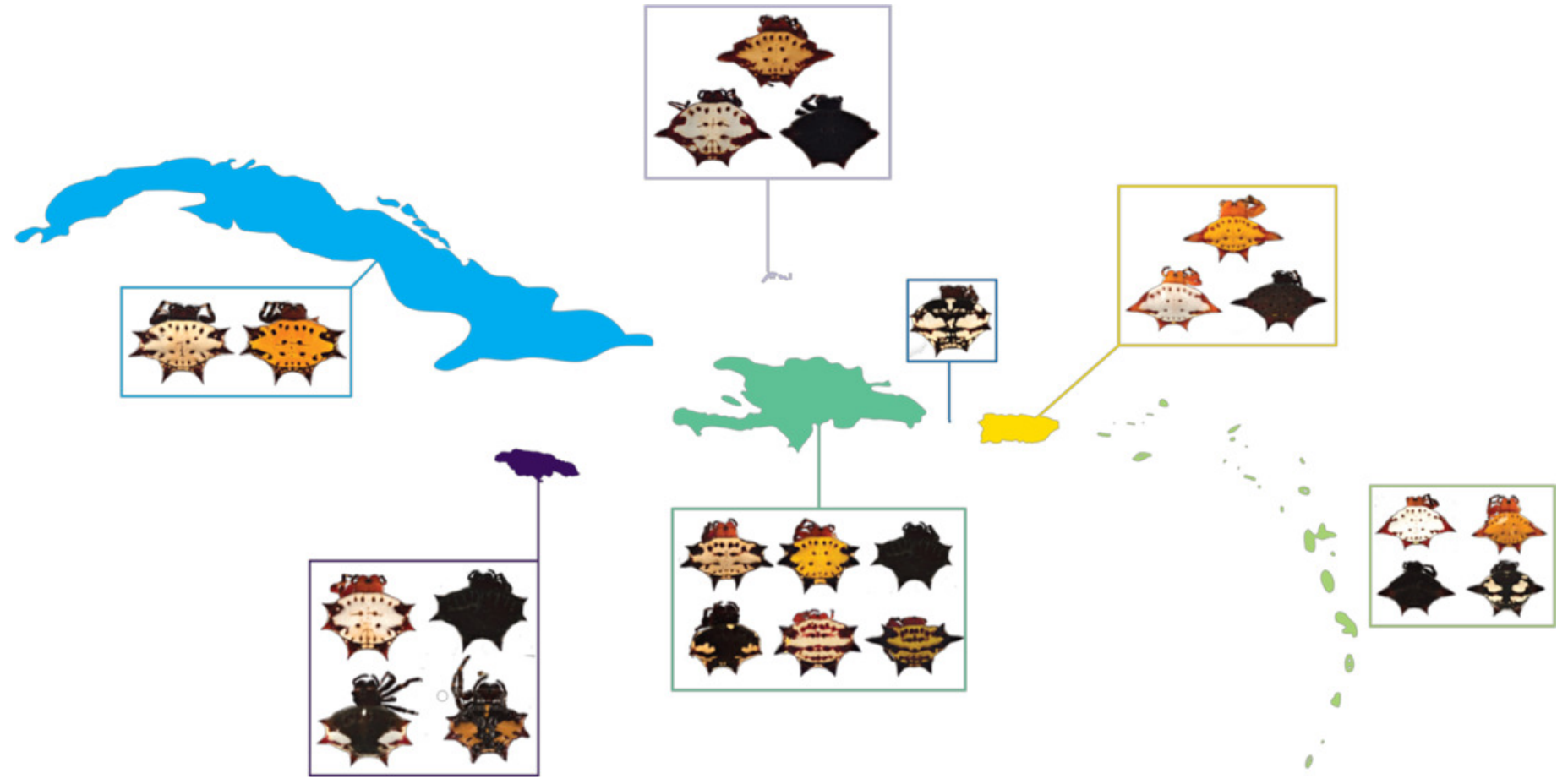


\section{Figure 2}

\section{Beast divergence times estimations of concatenated phylogeny.}

Dataset was pruned to exclude redundant taxa and individuals with $>65 \%$ missing data. Nodes are labeled with BI posterior probability values; any nodes with $\mathrm{pp}<0.75$ are not labeled. The colors indicate broad geographic location (blue = Caribbean, yellow $=$ North, Central, and South America - west of the Andes, red $=$ South America - east of the Andes) of individuals. There is one specimen within the Caribbean clade from SEUS (indicated by the black star). Major lineage divergence times and $95 \%$ highest posterior density of the A) Caribbean and SEUS clade and B) mainland clades.

(Image credit: https://photojournal.jpl.nasa.gov/catalog/PIA03377;

https://photojournal.jpl.nasa.gov/catalog/PIA03388) 


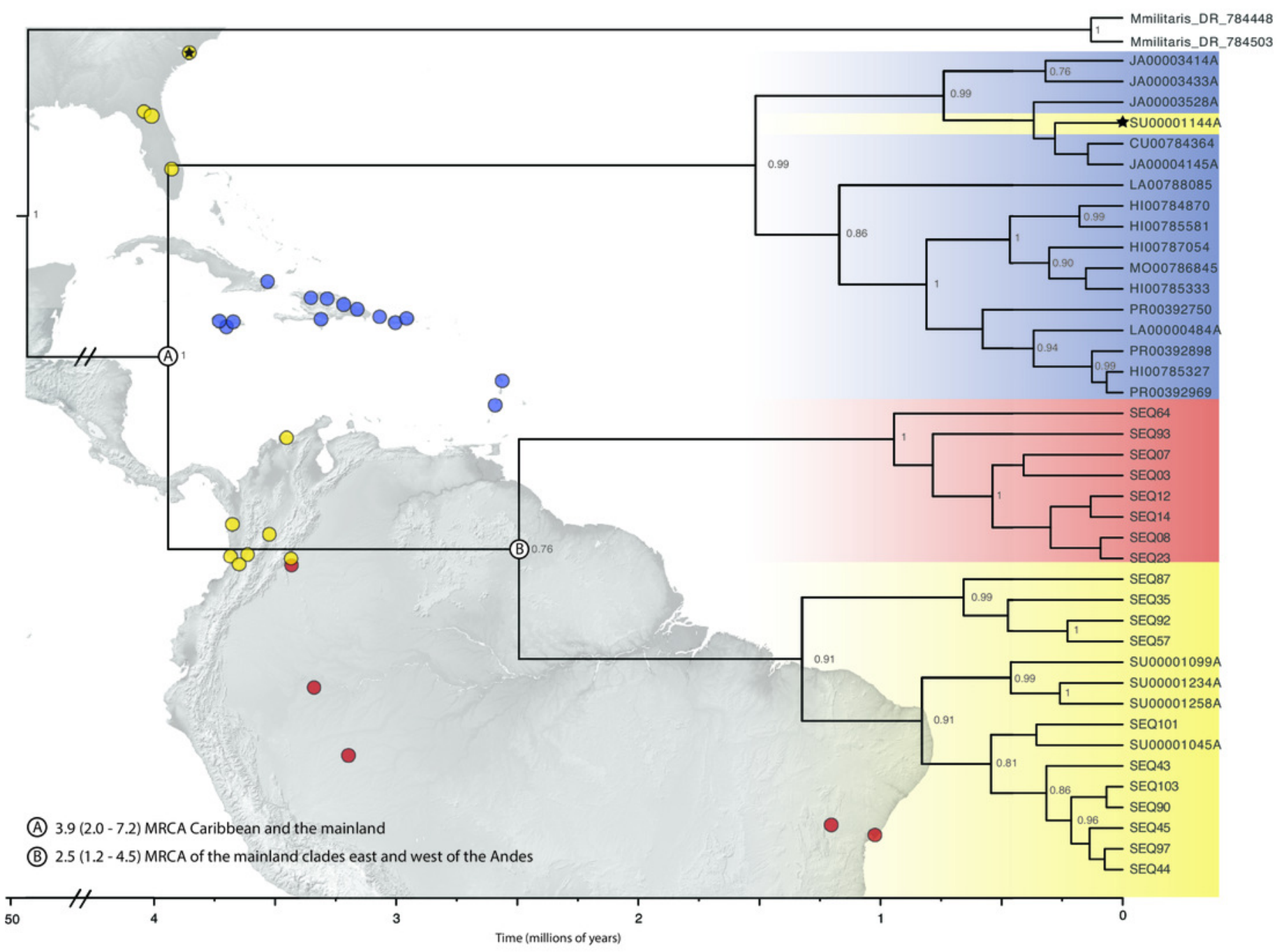


Figure 3

Haplotype network (COI) of Gasteracantha collected in the Caribbean and North, Central, and South America.

Pie charts are colored by geographic location and are proportional to the number of individuals sharing the haplotype. A) Polymorphism variation is high even within single islands. B) color is not specific to island, spines are highly specific to island regardless of phylogenetic placement. C) Even small islands, (e.g. TCl) have multiple colors morphs.

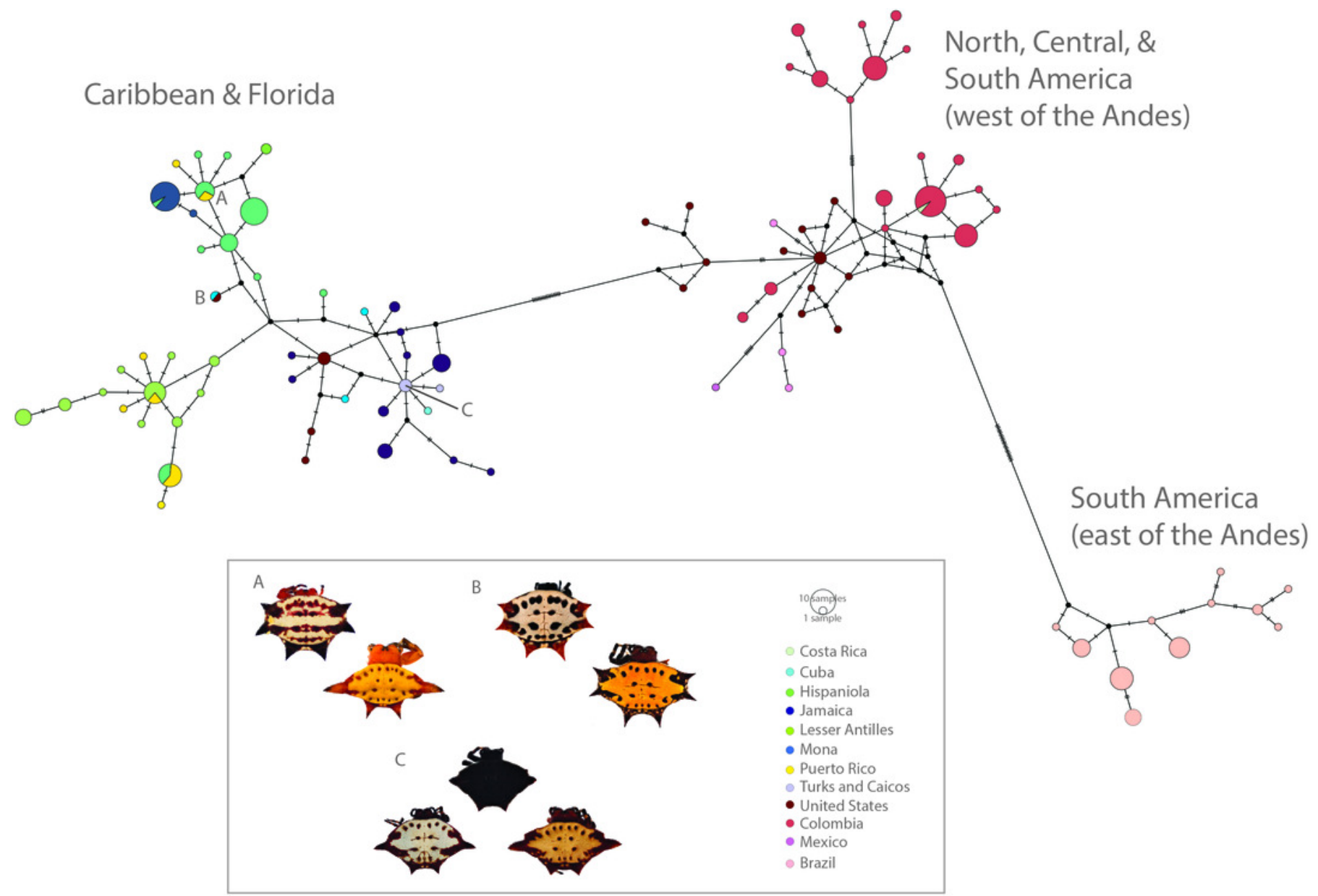




\section{Figure 4}

Population pairwise genetic diversity of G. cancriformis among 20 island populations.

A) map of major collection localities B) MCA plot of categorical variables geology (island), genetics (COI haplotype), and morphology (spine number and abdomen color). Grey dots represent observations, with darker shaded dots indicating higher concentration of individuals. Density curves surround highly concentrated zones. The first dimension explains $8.1 \%$ of the variance in our data and dimension two explains $6.9 \%$ of the variance. C) heatmap of $F_{\mathrm{ST}}$ values (blue hues) and within population haplotype diversity across the diagonal (orange hues) of the COI Caribbean dataset. 
A

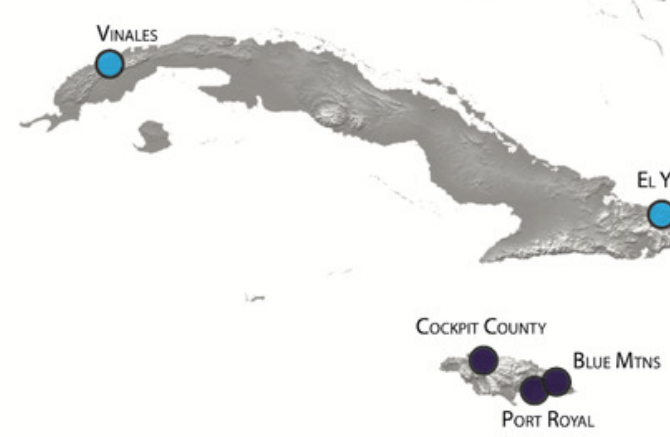

B

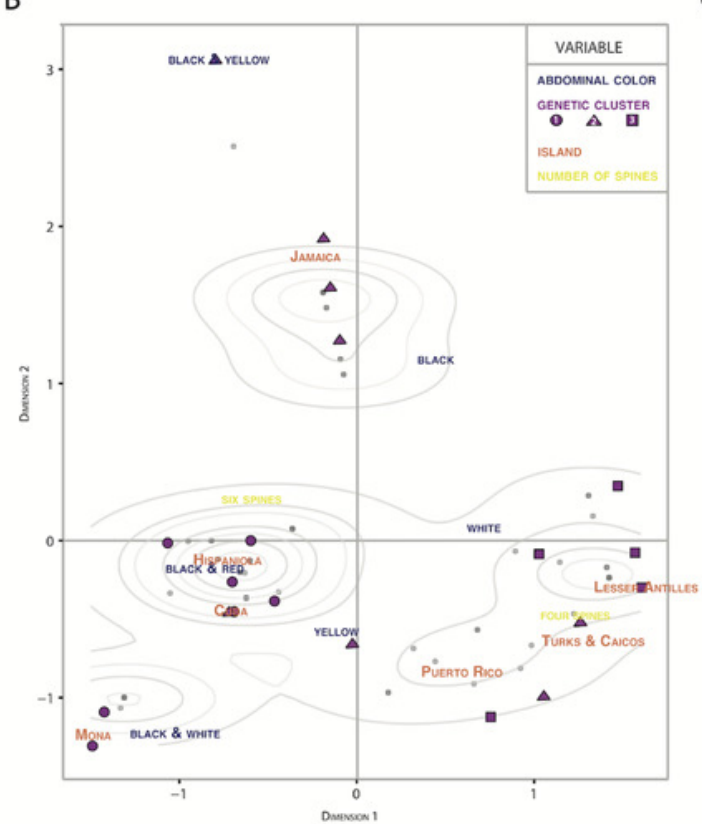

Turs \& Calcos

$-0$

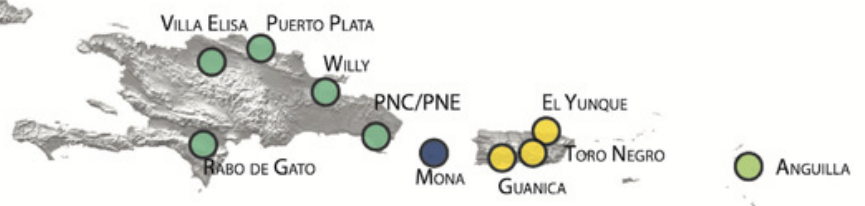

C

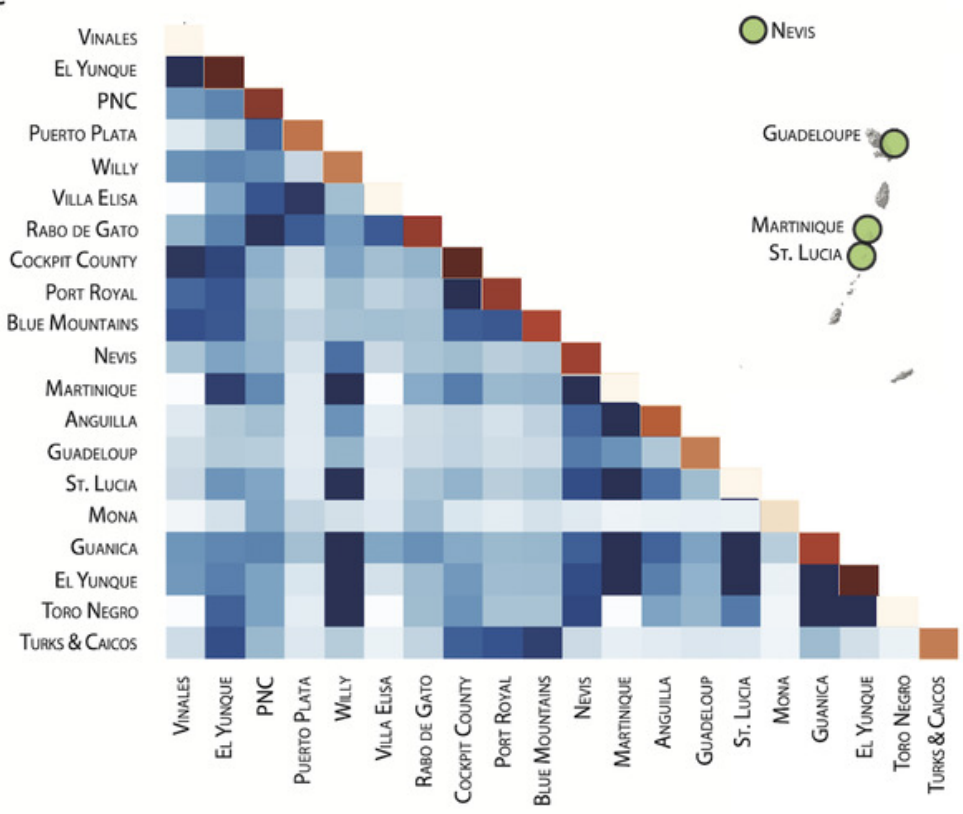




\section{Table 1 (on next page)}

Analysis of molecular variance between and among G. cancriformis island populations. 
1

\begin{tabular}{ll}
\hline Source of Variation & Percent Variation \\
\hline COI &
\end{tabular}

Among islands $\quad 49.21^{*}$

Among populations within islands $16.75^{*}$

Within populations $34.04^{*}$

$16 S$

Among islands

$-0.39$

Among populations within islands $\quad 0.75$

Within populations $\quad 99.64$

2

3

4 


\section{Table 2 (on next page)}

$\mathrm{COI}$ summary statistics for populations of $G$. cancriformis sampled in the Caribbean islands.

$\mathrm{N}=$ number of individuals, $\mathrm{h}=$ number of haplotypes, $\mathrm{S}=$ number of segregating sites, $\mathrm{Hd}=$ haplotype diversity +/- SD, pi = nucleotide diversity +/- SD, D = Tajima's D. 
1

\begin{tabular}{|c|c|c|c|c|c|c|c|}
\hline Island & $\mathbf{N}$ & $h$ & $\mathbf{S}$ & $H d \pm S D$ & $\pi(p i)$ & $\begin{array}{l}\text { Theta per site } \\
\text { from S. Theta W }\end{array}$ & $\begin{array}{l}\text { Tajimas D } \\
\text { (D) }\end{array}$ \\
\hline Cuba & 4 & 4 & 8 & $1 \pm 0.177$ & 0.00819 & 0.00825 & -0.06867 \\
\hline Hispaniola & 37 & 11 & 16 & $0.815 \pm 0.048$ & 0.00513 & 0.00725 & -0.9541 \\
\hline Jamaica & 20 & 10 & 14 & $0.879 \pm 0.052$ & 0.00596 & 0.00746 & -0.73613 \\
\hline $\begin{array}{l}\text { Lesser } \\
\text { Antilles }\end{array}$ & 24 & 10 & 9 & $0.870 \pm 0.045$ & 0.00444 & 0.00456 & -0.08468 \\
\hline Mona & 16 & 2 & 1 & $0.125 \pm 0.106$ & 0.00024 & 0.00057 & -1.16221 \\
\hline Puerto Rico & 14 & 7 & 11 & $0.813 \pm 0.094$ & 0.00654 & 0.00654 & 0.00292 \\
\hline $\begin{array}{l}\text { Turks \& } \\
\text { Caicos }\end{array}$ & 4 & 2 & 1 & $0.500 \pm 0.0265$ & 0.00095 & 0.00103 & -0.61237 \\
\hline Total & 119 & 42 & 39 & 0.94730 & 0.00973 & $\begin{array}{l}F_{\mathrm{ST}}=0.57588 \\
\mathrm{~K}=5.14855\end{array}$ & \\
\hline
\end{tabular}

2 